\title{
LET US BE JUDGED BY OUR ACTIONS OVERSIGHT MECHANISMS OF POLICING IN COMPARATIVE OUTLINE
}

\section{Aleksandra Wentkowska*}

\begin{abstract}
The oversight of police conduct is a fundamental governance issue and relates to concerns about democratisation and the building of a civil society. The subject of this paper is to outline the general mechanism of the oversight of police. The establishment of oversight institutions over the police is undoubtedly a key element in democratic policing. Another aim is to explain the development of the idea of resident oversight of the police, which offers some organizational examples that have been developed in some countries around the world. Examples from the UK, India and the USA revealed that oversight mechanisms vary from one country to another in terms of establishment and sustainability. The paper submits the reasons for the independent investigation of police complaints and for restoring confidence in the complaints system and in policing.
\end{abstract}

In democratic states, the police and special services should provide security to the state and its citizens, that is protection against internal and external threats. Safety is undoubtedly located high in the hierarchy of goods protected by law. It is rightly pointed out in legal literature that safety is a state, which 'gives the individual the feeling of elementary value, which

* PhD in law sciences, Associate Professor at the Department of Theory and Philosophy of Law at the Silesian University, Field Plenipotentiary of the Commissioner of Human Rights in Poland. 
is its existence and a guarantee of the preservation and continuity of that existence, it allows further development and self-improvement. ${ }^{1}$ However, one cannot forget that police activities, in their essence, significantly interfere with fundamental freedoms and human rights. Not always and not in any area can such interference be justified by security reasons. When the police are required to use force to achieve a lawful objective, such as making a lawful arrest, acting in self-defence or protecting others, all force used must be reasonable under the circumstances. The use of force by police officers can result in judicial proceedings in both the criminal and civil courts. Safety is, without a doubt, one of the most important legal goods, but not the only one. It is also not absolute, which means that it may be subject to restrictions due to collisions with other 'goods.' In other words, actions aimed at protecting the safety of citizens cannot interfere with other legal goods, including human rights and freedoms. Should the range of permissible interferences be large, this would lead to the risk of significant abuses involving the use of broad powers by the state authorities in order to exercise less common rights.

The legal instruments surrounding the use of force or operational surveillance must be constructed on the basis of an informed and in-depth study on the collision of protected goods, in this case the most important goods for a political community, include human dignity, common good and the principle of democratic rule of law. ${ }^{2}$ The authorities protecting human rights are appointed to conduct intensive checks, verifying whether the confines of proportionality of using operational and investigative activities in a democratic state have not been breached. Restrictions imposed on police services and special services may result, to a certain extent, in an increased risk of danger, however, a far-reaching limitation of these risks would be possible only through the construction of an omnipotent and - ultimately - totalitarian state.

The police, as the state institution which protects people's rights and safety, holds a unique position in society to enforce the power of the state and law. Enforcing this power and law involves effective discretion

1 M. Ławrynowicz-Mikłaszewicz, Bezpieczeństwo jako prawo człowieka w kontekście stosowania środków przymusu bezpośredniego i broni palnej przez uprawnione podmioty [Security as a human right in the context of measures using direct coercion and unauthorised firearms], 'Przegląd Prawniczy, Ekonomiczny i Społeczny' 2014, no. 4, p. 64.

2 M. Safjan, Wyzwania dla państwa prawa [Challenges for the rule of law], Warszawa 2007, pp. 61-62. 
and decision making. The misbehaviour or inefficiency of a police officer may hinder the public trust in the state authorities, therefore states and societies have developed specific methods and legal systems in regard to this. These methods are divided in two general types of control: external and internal. The external control of the work of the police is performed by state institutions such as the government, competent judicial bodies, state administration bodies responsible for certain supervisory duties, and other bodies and structures authorised thereto by law. Following the internal control, police organizations themselves control the behaviour and conduct of officers by setting up their own audit or internal investigation functions. When the police organization itself is responsible for misconduct, these internal remedies have proven inadequate as catalysts for addressing systemic problems in police departments. ${ }^{3}$ Therefore, there is a need to establish an oversight scheme that is external to the existing internal method because "no system, however elaborate, which concentrates on supervision and ex post facto review of police investigations will satisfy the demand that justice will only be seen to be done when the investigation of complaints against the police is taken out of the hands of the police themselves. ${ }^{4}$ The need to establish an independent system for the investigation of police complaints is also noticed by many academics and writers on the subject. ${ }^{5}$

3 K. Simmons, The Politics of Policing: Ensuring Stakeholder Collaboration in the Federal Reform of Local Law Enforcement Agencies, 'Journal of Criminal Law and Criminology' 2008, vol. 98, no. 2.

4 J. Lambert, Police Powers and Accountability, Croom Helm, Kent 1982, p. 82.

5 I. Freckelton, Shooting the Messenger: The Trial and Execution of the Victorian Police Complaints Authority [in:] A. J. Goldsmith (ed.) 'Complaints Against the Police: The Trend to External Review' Clarendon, Oxford 1991, p. 63-114; M. Maguire, Complaints against the Police: The British Experience [in:] A. J. Goldsmith, op.cit., pp. 177-210; C. Lewis, Complaints against Police - The Politics of Reform, Hawkins, Sydney 1999; C. Beattie, R. Weitzer. Race, Democracy and Law: Civilian Review of Police in Washington, DC [in:] A. Goldsmith, C. Lewis, (eds.), 'Civilian Oversight of Policing' Hart Publishing, Oxford 2000, p. 41-62; B. Manby, The South African Independent Complaints Directorate [in:] A. Goldsmith, C. Lewis, op. cit., pp. 195-222; R. Neild, Confronting the culture of Impunity: The Promise and Pitfalls of Civilian Review of Police in Latin America [in:] A. Goldsmith, C. Lewis, op. cit., pp. 223-258; B. Milton-Edwards, Called to Account: Civilian Oversight in the Palestinian Context [in:] A. Goldsmith, C. Lewis, op. cit., pp. 295-322; B. A. Buren, Evaluating Citizen Oversight of Police, LFB Scholarly Publishing, New York 2007; D. H. Bayley, Changing the Guard: Developing Democratic Policing Abroad, Oxford University Press, New York 2006; 
The aim of this paper is to outline the general oversight of police mechanism. Another aim is to explain the development of the idea of police's resident oversight, which offers some organizational examples that have been developed in some countries around the world. This paper submits reasons for an independent investigation of police complaints and for restoring confidence in the complaints system and in policing. For this paper, the term oversight of the police will be associated with institutions outside the police, which have power to check the way police departments handle complaints about questionable police conduct.

\section{State, democracy and police}

In the literature disputes about civilian oversight focus on two separate concepts: policing for democracy and democratically responsive policing leading to the question of what makes policing 'democratic' and the best manner of achieving it. ${ }^{6}$ It is extremely difficult to offer one model and definition of democracy policing, because 'the search for a broad and theoretically informed definition is somewhat disappointing in that none links the broader political and philosophical principles to the definitions

N. W. Pino, M. D. Wiatrowski Democratic Policing in Transitional and Developing Countries, Ashgate 2006.

A. Aitchison, Police Reform in Bosnia and Herzegovina: State, Democracy and International Assistance. 'Policing and Society' 2007, vol. 17, no. 4, p. 321-343; J. Alderson, Policing Freedom, Dilemmas of Policing in Western Democracies, Plymouth 1979; M. Amir, S. Einstein (eds.), Policing, Security and Democracy: Theory and Practice, Office of International Criminal Justice, Huntsville 2001; S. Baranyi, J. B. Salahub, Police reform and democratic development in lower-profile fragile states, 'Canadian Journal of Development Studies' 2011, 321, p. 48-63; D. Bradley, N. Walker, R. Wilkie, Managing the Police: Law, Organisation and Democracy, Wheatsheaf, Brighton 1986; D. Das, O. Marenin (eds.), Challenges of Policing Democracies, Gordon and Breach Science Publishers, Newark 2000; D. R. Mansley, Collective Violence, Democracy and Protest Policing, Routledge, London 2013; P. K. Manning, Democratic Policing in a Changing World, Paradigm, Boulder 2010; M. Marks, A. Goldsmith, The state, the people and democratic policing: the case of South Africa [in:] J. Wood, B. Dupont (eds.) Democracy, Society and the Governance of Security Cambridge University Press, 2006; T. Newburn, M. Hinton (eds.), Policing Developing Democracies, Routledge, London 2008; B. F. Smit, C. J. Botha, Democracy and policing: an introduction to paradox, 'Acta Criminologica' 1990, vol. 3, no. 1. 
offered'. ${ }^{7}$ In general both concepts cover support for the establishment or maintenance of democracy, and specific arrangements for the democratic governance of police services. Some authors indicate prescriptions for democracy or evaluative schemes for police services and police governance, or lists of values to inform police reform. ${ }^{8}$ The comprehensive and descriptive idea posited by K. Manning who suggests that democratic policing in 'some ways reflects and refracts the state and its interests, but these interests are balanced, on the one hand, between these of police as agents and, on the other, those of citizens.'

Civilian oversight of policing should then be seen as consistent with democracy, particularly specified as the significant power the police hold over citizens. Therefore, citizen oversight of police was intimately tied to the issue of civil or human rights and should be examined in the context of a democratic legal state. The emergence of citizen oversight of the police is an issue that is characteristic for political and social systems based on democratic principles. ${ }^{10}$ The principle of equity and police capacity to provide a certain minimum threshold of security were identified in the discussion of policing for democracy and encompass the values of service delivery, efficiency, effectiveness and to be 'responsive to some expression of the views of the public.' ${ }^{11}$ Moreover, the criterion of accountability is extremely important, whereby police 'must accept that they have to explain themselves... to outsiders who pay for their salaries, supply their resources and suffer the consequences of their work ${ }^{12}$ The point for police accountability and the investigation of complaints based on the assumption that if citizens are to have confidence in police services as a whole, they must feel

7 P. K. Manning, Democratic policing in a changing world. Paradigm Publishers, London 2010, p. 37.

8 For example, O. Marenin, The Goal of Democracy in International Police Assistance Programs, 'Policing; an International Journal of Police Strategies and Management' 1998, vol. 21, no. 2, pp. 159-177; T. Jones, T. Newburn, D. Smith, Policing and the Idea of Democracy, 'British Journal of Criminology' 1996, vol. 36, no. 2, p. 191.

9 P. K. Manning, Democratic policing..., op.cit., p. 37.

10 Ch. E. Stone, H. H. Ward, Democratic Policing: A Framework for Action, 'Policing and Society' 2000, vol. 10, no. 1, p. 11-45.

11 O. Marenin, op. cit., pp. 169; T. Jones, T. Newburn, D. Smith, Policing and the Idea of Democracy, 'British Journal of Criminology' 1996, vol 36, no. 2, p. 191; A. Aitchison, J. Blaustein, Policing for Democracy or Democratically Responsive Policing? Examining the Limits of Externally Driven Police Reform, 'European Journal of Criminology' 2013, vol. 10, no. 4, pp. 496-511.

12 O. Marenin, op. cit., p. 170, P. K. Manning, Democratic policing..., op. cit., p. 68. 
that when they complain about individual instances of police misconduct, their allegations will be investigated thoroughly and impartially. ${ }^{13}$

Public reactions to and attitudes toward the powers, decisions and behaviour of the police are rooted in the development of the police as a community mechanism for safeguarding security and safety. Therefore, building trust with citizens should be the basis of more effective and beneficial policing in a community. The principle of trust in the state and the law laid down by it is based on the requirement of legal certainty. Therefore such a combination of characteristics conferred by law, which provides the individual with legal certainty, permit the individual to decide on their actions based on a complete knowledge of the circumstances surrounding the actions of the state authorities and the legal consequences the individual's actions may entail. The principle of trust in the state cannot be understood only in a formal way, as a procedurally correct adoption of provisions, or the publication thereof, regardless of their content. The substantive aspect of legislative activities, considering the scope of regulatory activities of the legislature, its contents and the decisions taken in relation to democratic standards and the rule of law, is of fundamental importance from the perspective of the citizen and their relation to the state. There is a reason it is called the principle of citizens' loyalty to the state. The principle of the citizens' trust in the state (loyalty) 'refers not only to the procedure and form of the adopted law. The entire process of the application of the law, beginning with its interpretation, should be carried out in compliance with this principle. ${ }^{14}$ The principle of citizens' trust in the state should be understood even wider. It consists also of the formally appropriate process of legislation, the introduction of vacatio legis and the stability of interpretation. The principle of loyalty is realized already at the stage of the formulation of the content of the provisions. There is no way to maintain the relationship of trust and loyalty if a state is shaping up its powers in such a way as to seriously interfere in the freedom and rights of citizens and not indicating the limits of the use of these powers, or setting limits

13 J. Harrison, M. Cunneen, An Independent Police Complaints Commission, Liberty 2000, p. vii.

${ }_{14}$ W. Sokolewicz, Komentarz do art. 2 [A commentary to article 2], [in:] L. Garlicki (ed.), Konstytucja Rzeczypospolitej Polskiej. Komentarz [Constitution of Republic of Poland. A commentary], vol. V, Warszawa 2007, p. 34. Cf. also judgement of the Constitutional Tribunal of 27.11.1997, ref. U 11/97. 
in excess of the principle of proportionality. This problem is noticeable in the context indicated in this application.

The interference in the rights and freedoms of citizens should be examined in light of the principle of proportionality. The principle of proportionality requires firstly that the restrictions on the exercise of constitutional rights and freedoms be introduced in the form of a statute, which excludes their normalization using acts of a lower rank. Secondly, in substantive aspects this principle allows the establishment of only restrictions, which do not affect the substance of a given freedom or subjective right, and only when there is a need for their introduction in a democratic state for its security or public order, or to protect the environment, health, public morals, or the freedoms and rights of others. Importantly, the scope of the restrictions should be proportionate, i.e. necessary to achieve a particular purpose. Accordingly, three criteria are reconstructed: relevance, necessity and proportionality in the strict sense of the adopted limitations. Such interference is admissible if it can bring the intended effects, it is necessary to protect the public interest with which it is associated, and its effects are proportionate to the burdens imposed by it on the citizen. ${ }^{15}$ Any regulation concerning the activities of the police authorities which leads to restrictions on the exercise of freedoms and rights, requires the penal legislature to prove in each case that the proposed regulatory decision meets the criteria of the proportionality test. The legislature should first determine the purpose of the proposed standard, demonstrate its necessity in light of the intended purpose, its usefulness in attaining it, and finally test the preference implied by the collision between the good, which it wants to protect, and the good associated with the rights and freedoms that the planned regulation prejudice.

All these principles result also directly from the European Convention on Human Rights ${ }^{16}$ and a host of judgements of the European Court of

15 K. Wojtyczek, Zasada proporcjonalności jako granica prawa karania [The principle of proportionality as a limit to the right to punish], [in:] A. Zoll (ed.), Racjonalna reforma prawa karnego [A rational reform of criminal law], Warszawa 2001, p. 297; M. Piechowiak, Klauzula limitacyjna a nienaruszalność praw i godności [The limitative clause and the inviolability of rights and dignity], 'Przegląd Sejmowy' 2009, no. 2, pp. 56-57; A. Stępkowski, Zasada proporcjonalności $w$ europejskiej kulturze prawnej [The principle of proportionality in european legal culture], Warszawa 2010, at p. 194; A. Zoll, Konstytucyjne aspekty prawa karnego [Constitutional aspects of criminal law], [in:] T. Bojarski (ed.), Źródła prawa karnego [Sources of criminal law] System Prawa Karnego, vol. 2, Warszawa 2011, pp. 237-241.

16 Rome, 4.11.1950. 
Human Rights. Article 2 of the Convention, which safeguards the right to life and sets out the circumstances when deprivation of life may be justified, ranks as one of the most fundamental provisions in the Convention, from which no derogation is permitted. Together with article 3 which prohibits torture and inhuman and degrading treatment or punishment, it also enshrines one of the basic values of democratic societies making up the Council of Europe. ${ }^{17}$ The use of lethal force by the State was first addressed in details in the McCann and Others v. the UK judgment, according to which article 2 allows for exceptions to the right to life only when it is 'absolutely necessary', a term indicating 'that a stricter and more compelling test of necessity must be employed than that normally applicable when determining whether State action is 'necessary in a democratic society' under paragraphs 2 of articles 8 and 11 of the Convention. ${ }^{18}$ In another case, the Court found in particular that the Government had neither provided it with information in regulations for the prevention of abuse of official weapons by its agents nor with information as to whether the police reservist had been assessed to ensure that he was fit to be recruited and equipped with a weapon. ${ }^{19}$ The proportionality principle does not appear in the text of article 2 but is clearly established in the Court's case-law. In one Polish case, the Court stated that the Polish Government had failed to submit any comments regarding the proportionality of the level of force used by the police, the organization of the police action and whether an adequate legislative and administrative framework had been put in place to safeguard people against arbitrariness and abuse of force. ${ }^{20}$ Where use of force is legitimate and applied on the principles of necessity and proportionality the court does not consider this as violations of human rights.

17 Makaratzis v. Greece, judgment of the Grand Chamber of 20.12.2004, §56.

18 The case concerned the death of three members of the IRA, suspected of having on them a remote control device to be used to detonate a bomb. They were shot dead on the street by Special Air Service soldiers in Gibraltar. The Court concluded that there had been a violation of article 2 because the operation could have been planned and controlled without the need to kill the suspects. Judgment of 27.09.1995, § 149 .

19 Sašo Gorgiev v. 'The Former Yugoslav Republic of Macedonia', Judgment of 19.04.2012.

20 Wasilewska and Kalucka v. Poland, Judgement of 23.02.2010, see also Finogenov and Others v. Russia, Judgement of 20.12.2011. 
Demands for police reform and civil oversight are often the result of a crisis of confidence in the government, legal system and the police. ${ }^{21}$ The establishment of civilian oversight is often a difficult process, with necessary factors such as political support, police cooperation, activist support, resources, management and leadership and public attitudes. Some authors mention a number of criteria that can be used for assessing the success of oversight agencies, which include: integrity (whether the complaints process is fair, thorough and objective), legitimacy (how complaints processes are perceived) and learning (feedback from the process contributes to improvements). ${ }^{22}$ The efficacy of an oversight agency is also very much

21 E. E. Alemika, Police oversight agencies in West Africa, 2005, available at www.policeaccountability.co.za, p. 1; E. E. Alemika, Police reform and oversight, Police reform in Africa: Issues and challenges. IDASA, Police reform in post-conflict African countries conference, Pretoria, South Africa 12-15.3.2007, Institute of Criminology, Cape Town 2007; A. Aremu, F. Pakes, L. Johnston, The effect of locus of control in the reduction of corruption in the Nigerian police, 'Policing' 2009, vol. 32, no. 1, p. 144-56; T. Bierschenk, The everyday functioning of an African public service. Informalization, privatization and corruption in Benin's legal system, 'Journal of Legal Pluralism' 2008, vol. 57, p. 101-139; C. Casey, Policing through Violence: Fear, Vigilantism and the Politics of Islam in Northern Nigeria, [in:] D. Pratten, A. Sen (eds)., 'Global Vigilantes', Hurst, London 2007; A. W. Chanda, Lecture Series: Human Rights for Law Enforcement Officers, Zambia Legal Information Institute, 2004: http://www. zamlii.ac.zm/media/news/viewnews.cgi?category=2\&id=1069084655; M. Chingono, The State, Violence and Development: The Political Economy of War in Mozambique 1975-92, Aldershot 1996; S. Heald, Controlling Crime and Corruption from Below: Sungusungu in Kenya, 'International Relations' 2007, vol. 21, p. 183-199; G. Newham, T. Masuku, J. Dlamini, Diversity and Transformation in the South African Police Service: A study of police perspectives on race, gender and the community in the Johannesburg policing area, Centre for the Study of Violence and Reconciliation, 2006; M. Shaw, Crime and Policing in Post-Apartheid South Africa: Transforming under Fire, Hurst, London 2002; J. Tankebe, Public confidence in the police: testing the effects of public experiences of police corruption in Ghana', 'British Journal of Criminology' 2010, vol. 50, no. 2, p. 296-319; J. Tankebe, Police effectiveness and police trustworthiness in Ghana, 'Criminology and Criminal Justice' 2008, vol. 8, no. 2, p. 185-202; C. Tertsakian, State-sponsored terrorism. The Bakassi boys; the legitimization of murder and torture, 'Human Rights Watch' 2002, vol. 14, no. 5; A. von Schnitzler, G. Ditlhage, L. Kgalema, T. Maepa, T. Mofokeng, P. Pigou, Guardian or Gangster? Mapogo a Mathamaga: A Case Study. Violence and Transition Series 2001, vol. 3, available at http://www.csvr.org.za/papers/papvtp3.htm.

22 J. Miller, Civilian oversight of policing. Lessons from the Literature, Vera Institute of Justice, Global Meeting on Civilian Oversight of Police, Los Angeles, 5-8.5.2002, http:// www.vera.org/publication_pdf/178338.pdf. 
contingent upon its political context. ${ }^{23}$ Then, the fundamental issue in regard to oversight is not who does the investigating, but the terms on which it is done. ${ }^{24}$

\section{Types of control}

The police uphold the rule of law in democratic societies and are responsible for providing safety in accordance with the law safeguarding everybody's rights and freedoms, which may only be restricted under the conditions and in the manner provided by the law. These functions should be performed through professionalism, cooperation, legality and proportionality in using police powers, as well as the principle of subsidiarity and inflicting the least detrimental consequences. In the performance of police functions only such means and measures of the enforcement may be applied as are envisaged by the law, which helps to produce the most professional results without undue harm or delay. However, when the officer is responsible for an act of police misconduct, there are some internal and external remedial responses available to address his conduct, ranging from a judicial intervention, a state prosecution of police officers, a federal prosecution of police officers, tort suits by aggrieved citizens and internal police investigations to a citizen review of police misconduct.

Internal supervision of the work of the police is usually performed by special departments for the internal supervision of the police. In alleged cases of police misconduct the internal department receives the complaint,

23 F. Harris, Holding Police Accountability Theory to Account, 'Policing: Journal of Policy and Practice', vol. 6, no. 3, p. 246; R. Neild, 'Confronting the culture of Impunity: The Promise and Pitfalls of Civilian Review of Police in Latin America.' [in:] A. Goldsmith, C. Lewis, (eds), 'Civilian Oversight of Policing', Hart Publishing, Oxford 2000, p. 233; J. Flemming, C. Lewis, The Politics of Police Reform, [in:] T. Prenzler, J. Ransley (eds), 'Police Reform - Building Integrity', Hawkins Press, Annandale 2000, p. 94; B. A. Buren, Evaluating Citizen Oversight of Police, LFB Scholarly Publishing, New York 2007, p. 37; B. Loveday, Government and Accountability of the Police, [in:] R. I. Mawby (ed.) 'Policing across the World: Issues for the Twenty-first Century', Routledge, London 1999, p. 149.

24 F. Harris, Holding Police Accountability Theory..., op. cit., p. 246; R. Reiner, Multiple Realities, Divided Worlds: Chief Constables' Perspectives on the Police Complaints System, [in:] A. J. Goldsmith (ed.), 'Complaints Against the Police: The Trend to External Review', Clarendon, Oxford 1991, p. 228; G. Smith, Rethinking Police Complaints, 'The British Journal of Criminology' 2004, vol. 44, no 1, p. 15. 
investigates the issue, and then determines the appropriate sanction, if the officer has not been exonerated. Questionable police conduct could be wide and varied, including issues that are either clearly criminal in nature or suspected of being so. Then, there are possible procedural violations of a person's constitutional or civil rights, are viewed as unsuitable deviations from the policies and procedures of the department, or are simply inappropriate actions by a public employee. Therefore, police are in need of an external oversight scheme. It is due to the nature of police tasks (the power to detain people in connection with an offence, to stop and search for people/vehicles in connection with offences (actual or suspected), to arrest people without a warrant for minor offences, and others), the powers deferred to the organization, and significant discretion accorded to individual police officers. Moreover, as the Australian Law Reform Commission concluded 'the record of internal units is generally inadequate in terms of the effective conduct of investigations and there are excessive delays. A siege like mentality of police officers and their own police culture means that there are strong risks that they will not be able to conduct thorough and fair investigations. ${ }^{25}$

External supervision, independent from the internal department audit covers exclusive and inclusive control. Government, prosecution, judicial and administrative oversight bodies fulfil the external and exclusive audit function, as well as state sponsored civilian oversight bodies like ombudsmen, human rights commissions or anti-corruption institutions. Parliament through its legislative power, as well as political parties (executive power), media and non-governmental organizations work as watchdogs.

There is a universal tendency to introduce civilian oversight over police across the world. The table below presents the following models:

25 Under the Spotlight: complaints against the AFP and NCA, Australian Law Reform Commission, Australia Government Publishing Service, 1995, pp. 194-195. 


\begin{tabular}{|c|c|c|}
\hline \multicolumn{3}{|c|}{ MODELS OF CIVILIAN OVERSIGHT OVER POLICE ACROSS THE WORLD } \\
\hline $\begin{array}{l}\text { TYPES OF } \\
\text { EXTERNAL } \\
\text { CONTROL }\end{array}$ & MAIN CHARACTERISTICS & EXAMPLES \\
\hline \multirow{3}{*}{ EXCLUSIVE } & $\begin{array}{l}\text { - Fully independent institutions } \\
\text { - Receives complaints from the } \\
\text { public } \\
\text { - Investigations conducted by } \\
\text { non-officers } \\
\text { - Reports findings to police }\end{array}$ & $\begin{array}{l}\text { 1. government } \\
\text { 2. parliamentary/government } \\
\text { commission } \\
\text { 3. citizen's commission } \\
\text { 4. courts and prosecutors } \\
\text { 5. oversight institutions, e.g.: } \\
\text { Police Ombudsman for } \\
\text { Northern Ireland } \\
\text { 6. Civilian Complaint Review } \\
\text { Board, New York, USA }\end{array}$ \\
\hline & $\begin{array}{l}\text { - Police investigation with citizen } \\
\text { review or appeal to civilian } \\
\text { authority } \\
\text { - Civilian authority or police } \\
\text { receives directly complaints } \\
\text { - Civilian authority may call for } \\
\text { further investigation if it does } \\
\text { not agree with police report }\end{array}$ & $\begin{array}{l}\text { 1. Independent Police Complaints } \\
\text { Commission - England and } \\
\text { Wales } \\
\text { 2. Independent Complaints } \\
\text { Directorate - South Africa } \\
\text { 3. Deputy Ombudsman } \\
\text { - Australia } \\
\text { 4. Police Complaints Authority } \\
\text { - India } \\
\text { 5. The Commission for Public } \\
\text { Complaints Against the Royal } \\
\text { Canadian Mounted Police }\end{array}$ \\
\hline & $\begin{array}{l}\text { - Broad mandate to investigate } \\
\text { and make recommendations } \\
\text { - May investigate individual cases } \\
\text { of alleged abuse }\end{array}$ & $\begin{array}{l}\text { Commissioner for Human } \\
\text { Rights - Poland }\end{array}$ \\
\hline INCLUSIVE & $\begin{array}{l}\text { Consultation, coordination and } \\
\text { control over broader legal acts, } \\
\text { policing policy and objectives }\end{array}$ & $\begin{array}{l}\text { 1. Parliament (via legislative } \\
\text { power) } \\
\text { 2. Political parties (via executive } \\
\text { power) } \\
\text { 3. Oversight institutions, } \\
\text { eg: National Association } \\
\text { for Civilian Oversight of } \\
\text { Law Enforcement, USA; } \\
\text { Independent Police Auditor - } \\
\text { San Jose, USA; Auditor - Sao } \\
\text { Paulo, Brazil }\end{array}$ \\
\hline
\end{tabular}

The tendency to form civil oversight over the police has been observed in the world since 1970. Before the 1970s, police misconduct was essentially handled internally within the police organization. Citizens oversight was an attempt to bring a degree of external oversight to the police. It is important to keep in mind that citizens oversight is not unique 
to the United States only. Among the countries that have been active in the development of oversight schemes are Australia, Canada and England. Model patterns of complaint mechanisms include England and Wales, and a relatively young institution in Northern Ireland. Other complaint systems around the world vary in their scope and level of powers in addition to independence. The nature of the involvement of civil complaint handling processes differs significantly among supervisory institutions from the full responsibility to examine complaints (Police Ombudsman for Northern Ireland) ${ }^{26}$, to the partial supervision over proceedings (South African Independent Complaints Directorate), ${ }^{27}$ and to surveillance and prompting ending (San Jose Auditor, California, USA). ${ }^{28}$ In addition to separate oversight mechanisms, internal reforms have also been introduced, with diversity in terms of both degree and style in different countries, in Asia also (the most popular institutions are: Human Rights Commissions, Anticorruption Organizations and Ombudsman). Most of these institutions in Asia, however, have specialties in policing and there are complaints against police not falling into any of these. ${ }^{29}$

26 Police (Northern Ireland) Act 1998 Elizabeth II. Chapter 32. HMSO: London. Police Ombudsman for Northern Ireland website (www.policeombudsman.org).

27 M. Bronwen, The South African Independent Complaints Directorate [in:] A. Goldsmith, C. Lewis, (eds), op. cit.; N. Melville, The Taming of the Blue: Regulating Police Misconduct in South Africa, Pretoria 1999.

28 B. Merrick, Civilian Oversight of the Police in the United States, 'Saint Louis University Public Law Review' 2003, vol. 22, no. 1; B. Merrick, Internal and External Oversight in the U.S. PARC issues paper, October 2005; P. Finn, Citizen Review of Police: Approaches and Implementation, National Institute of Justice, March 2001, http://www.ncjrs.gov/ pdffiles1/nij/184430.pdf; D.W. Perez, Common Sense About Police Review, Philadelphia 1994; Police Assessment Resource Center, Review of National Police Oversight Models for the Eugene Police Commission, February 2005; D. Livingston, The Unfulfilled Promise of Citizen Review, 'Ohio State Journal of Criminal Law' 2004, vol. 1, no. 2, p. 653-669; Revisiting 'Who is Guarding the Guardians?, November 2000, http://www.usccr.gov/pubs/pubsndx. htm; U.S. Commission on Civil Rights, Who is Guarding the Guardians? A Report on Police Practices, 1981; Vera Institute of Justice, Building Public Confidence in Police through Civilian Oversight, September 2002; S. Walker, The New World of Police Accountability, Thousand Oaks 2005; S. Walker, Police Accountability: The Role of Citizen Oversight, Wadsworth Professionalism in Policing Series, Belmont 2001.

29 P. Changwon, Background Report Examining Existing Police Oversight Mechanisms in Asia. Presented at the workshop: Improving the Role of the Police in Asia and Europe. Delhi, India, 3-4.12.2008, p. 1-3. 


\section{The Independent Police Complaints Commission}

The IPCC secures and maintains public confidence in the police complaints system in England and Wales, having powers to initiate, carry out and oversee investigations into complaints or allegations of misconduct and is also responsible for monitoring the way complaints are handled by local police forces. The Independent Police Complaints Commission (IPCC) was established by the Police Reform Act 2002 and became operational on 1 April 2004 as the guardian of the complaints procedure.

One of its statutory objectives is to increase public confidence in the police by demonstrating independence, integrity and accountability in the complaints system. Through their Guardianship function, the IPCC has a statutory duty to oversee the operation, performance and improvement of the police complaints system. ${ }^{30}$ The IPCC and its investigators as independent body have great powers of investigation and right of access to police premises, documents and information.

A person making a complaint can appeal to the IPCC if they feel they have not been given sufficient information by the police or if they are unhappy with the outcome of an investigation by the police. All complaints must be dealt with in accordance with legislation and guidance agreed upon by the Home Secretary. IPCC report publicly on the outcome of their investigations and make local and national recommendations as appropriate to help to ensure that the same thing does not go wrong again: Serious Organised Crime Agency (SOCA), Her Majesty's Revenue and Customs (HMRC) and UK Border Agency (UKBA). ${ }^{31}$

\section{The Police Complaints Authority}

The Police Complaints Authority (PCA) was formed by Govt. of N.C.T of Delhi in India vide Resolution No.F.12/04/2011/AR/1630-1789/C, dated 27.2.2012. The Police Complaints Authority was established to deal with the complaints of the public regarding acts of serious misconduct by the

30 S. Waseem, The Independent police complaints commission: who will guard the guardians? by Islamic Human Rights Commission, 2005.

31 Independent Police Complaints Commission Annual Report and Statement of Accounts 2011/12. 
policemen/officers of the Delhi Police. Any person having any grievance against police personnel regarding any misconduct as enumerated above may lodge a complaint in the PCA in the prescribed format. The PCA is comprised of a Chairman and three Members.

The Authority shall inquire into allegations of 'serious misconduct' against police personnel, either from the office or on a complaint received from a victim or any person on his/her behalf; the National or the State Human Rights Commission; the police or any other source. The Authority may also inquire into any other case referred to it by the Administrator/ Central Government. 'Serious misconduct' means any act or omission of a police officer that leads to or amounts to death in police custody; grievous hurt, as defined in Section 320 of the Indian Penal Code, 1860; rape or attempt to commit rape; arrest or detention without due process of law; extortion; land/house grabbing; or any incident involving serious abuse of authority. Provided that the Authority shall inquire into a complaint of such arrest or detention, only if it is satisfied prima facie about the veracity of the complaint.

The Police Complaints Authority has devised its own procedure and drafted standard operating procedure to ensure that the complaints received by it are dealt with promptly and in a transparent manner (Resolution No.F.12/04/2011/AR/1630-1789/C). The Authority may require any person or authority to furnish information on such points or matters as in the opinion of the Authority may be useful for or relevant to the subject matter of enquiry. The Authority, before finalising its opinion, shall give the Police Officer heading the police force in the National Capital Territory of Delhi an opportunity to present the department's view and additional facts, if any, not already in the notice of the Authority and in such cases, the Authority may review its findings upon receipt of additional information from the Police Officer heading the police force in the UT that may have a material bearing on a case. In the cases directly inquired by the Authority, it may, upon completion of the inquiry, communicate its findings to the Commissioner of Police Delhi with a direction to Register a First Information Report and/or initiate departmental action based on such findings, duly forwarding the evidence collected by it to the police. The directions of the Authority shall ordinarily be binding, unless for reasons to be given in writing, Govt. of the NCT of Delhi decides to disagree with the findings of the Authority. 


\section{American models}

Police abuse remains one of the most serious and divisive human rights violations in the United States. The excessive use of force by police officers, including unjustified shootings, severe beatings, fatal chokings, and rough treatment, persists because overwhelming barriers to accountability make it possible for officers who commit human rights violations to escape due punishment and often to repeat their offenses. ${ }^{32}$ The problem is nationwide, and its nature is institutionalized. For these reasons, the U.S. government - as well as state and city governments, which have an obligation to respect international human rights standards by which the United States is bound - deserve to be held accountable by international human rights bodies and international public opinion.

The National Association for Civilian Oversight of Law Enforcement (NACOLE) was created to realise the above assumptions. NACOLE is a nonprofit organization that brings together individuals and agencies working to establish or improve the oversight of police officers in the United States. The mission of NACOLE is to enhance fair and professional law enforcement responsive to community needs.

NACOLE, established in 1995, is incorporated under the laws of the State of Maryland. The organization has an elected board of directors composed of individuals in the field of citizen oversight of the police. The board manages the organization pursuant to a set of by-laws. NACOLE is dedicated to promoting greater police accountability through the establishment or improvement of citizen oversight agencies by organizing an annual training conference to increase the knowledge and skills of staff members and volunteers who work in oversight; providing technical assistance and advice to jurisdictions that are considering the creation or revitalization of oversight bodies; identifying best practices as they emerge from the experiences of members; encouraging networking, communication and

32 The Violent Crime Control and Law Enforcement Act of 1994 included a new statute under which the Justice Department may sue for declaratory relief (a statement of the governing law) and equitable relief (an order to abide by the law with specific instructions describing actions that must be taken) if any governmental authority or person acting on behalf of any governmental authority engages in: 'a pattern or practice of conduct by law enforcement officers... that deprives persons of rights, privileges, or immunities secured or protected by the Constitution or laws of the United States.' 'Police Pattern or Practice’ 42 U.S.C. §14141. 
information-sharing to counter the isolation inherent in the profession; furnishing information to government officials and community representatives that will support their advocacy of oversight in their states, counties, cities and towns.

NACOLE is committed to providing practitioners of oversight with the resources to develop the knowledge and skills needed to succeed. The Core Competencies for Civilian Oversight Practitioners provide guidance for self-study and a structure to ensure the Annual NACOLE Conference provides quality training in these key areas. These competencies were developed by members of the Professional Standards Committee, with input from the Board of Directors and membership to serve as a guideline for training as well as a rubric for conference planning and other organizational tasks, organizing the annual training conference; offering a professional credential; providing technical assistance and advice; identifying good practices and trends; and encouraging networking, communication, and information sharing to improve civilian oversight throughout the United States and internationally.

NACOLE provides for the establishment, development, education and technical assistance for the civilian oversight of law enforcement and develops a national forum to provide an informational and educational clearinghouse and a publication resource of educational information for the public and organizations in the field of civilian oversight of law enforcement. NACOLE encourages the highest ethical standards in organizations which oversee law enforcement and educates the public by developing mechanisms to enhance police and community relations, educate law enforcement agencies, and encourage law enforcement to respond with sensitivity to citizens' issues and complaints.

As can be noticed, civilian oversight over police in the United States varies from local government to local government, because there are no federal or state standards. Each type of system has its advantages and drawbacks. The roots of oversize is a response for the expectations of the local community to resolve problems concerning inappropriate police activity. Therefore, oversight plays an integral part of municipal governments in most large cities in the United States, as well as in smaller municipalities and counties. These agencies with jurisdiction over sheriff's offices have the authority to review incidents that take place in custodial, extreme issues of excessive force, death cases, corruption, as well as patrol settings. In some cities, appointed monitors have been installed through a consent decree or by the Department of Justice (in the cities of Detroit, Cincinnati and Oakland, and the New Jersey State Police, and four past appointed 
monitors in the cities of Los Angeles and Pittsburgh, the Metropolitan District of Columbia Police and Prince George's County). In the opinion of Attard, the efficacy of oversight organizations is difficult to measure-this may be due in part to the many goals of oversight, some of which may be conflicting (two objectives of impartially evaluating complaints and responding to community interests). ${ }^{33}$ Although there is no single model of citizen oversight, most procedures have features that fall into one of four types of oversight systems ${ }^{34}$ :

\subsection{Citizens investigate allegations of police misconduct and recommend findings to the chief or sheriff. Example: New York City Civilian Complaint Review Board (CCRB)}

The CCRB is an independent agency. The NYC Civilian Complaint Review Board was established as an all-civilian agency in 1993. It is empowered to receive, investigate, mediate, hear, make findings, and recommend action on complaints against New York City police officers who are alleged to have used excessive or unnecessary force, abused authority, been discourteous, or used offensive language. The Board's investigative staff, composed entirely of civilian employees, conducts investigations in an impartial fashion. CCRB encourage members of the community to file complaints when they feel they have been victims of police misconduct, and encourage all parties involved in a complaint to come forward and present evidence. Respecting the rights of civilians and officers, CCRB investigates each allegation thoroughly and impartially. CCRB makes objective determinations on the merits of each case and recommends disciplinary actions that are fair and appropriate, if, and when, the investigative findings show that misconduct has occurred. The thirteen-member board, headed by a chair, hires an executive director, who manages the agency's daily operations. The Board forwards its findings to the police commissioner.

33 B. Attard, Oversight of Law Enforcement is Beneficial and Needed-Both Inside and Out, 'Pace Law Review' 2010, vol. 30, no. 5, Opening Up a Closed World: A Sourcebook on Prison Oversight, p. 1550.

${ }^{34}$ P. Finn, op. cit., p. vii; B. Attard describes three basic forms of oversight as some variations incorporated in many cities in United States: investigative; boards and commissions and auditor/monitor agencies (op. cit., p. 1550). 
On 2.4.2012, the CCRB and the NYPD signed a Memorandum of Understanding (MOU) under which prosecutorial authority for the substantiated misconduct cases against police officers was transferred from the NYPD to the CCRB. Under the terms of the MOU, CCRB attorneys rather than police department lawyers prosecute officers at administrative trials, when the board has recommended charges for substantiated misconduct. As a part of its oversight function, the CCRB monitors activities on broader policing issues and makes recommendations to the police commissioner when it finds credible information that raises concerns about departmental policies, procedures or training.

The CCRB issues a minimum 14 reports per year to fulfil its mandate to inform the public and New York City elected officials about agency operations, complaint activity, case dispositions and police department discipline. In addition, the agency issues reports and recommendations on NYPD policies, procedures and training. As the largest civilian oversight agency in the country, the CCRB has investigated tens of thousands of complaints, leading to the disciplining of thousands of police officers.

\subsection{Police officers investigate allegations and develop findings; citizens review and recommend that the chief or sheriff approve or reject findings. Example: Rochester Civilian Review Board (CRB)}

The purpose of $C R B$ is to review and make recommendations on completed internal affairs investigations of alleged misconduct by employees of the Rochester Police Department. CRB falls under The Centre for Dispute Settlement (The Centre or CDS). Groupings of three CRB panellists are selected on a rotating basis from a pool of qualified individuals of varied ethnic, racial, age and gender backgrounds. Each board contains varied representation, given panellist availability. The panellists have received extensive training in their role as impartial reviewers as well as in police procedures and policies. From the list of $\mathrm{CRB}$ panellists, Chairpersons are nominated by CDS for Mayoral approval and appointment. The Chairs are responsible for all administrative duties before, during and after a CRB, as well as maintaining appropriate focus, impartiality and processing in the CRB.

The determining criteria for an investigation to be reviewed by the $\mathrm{CRB}$ are allegations of actions that would constitute a crime, and allegations 
involving the use of force. The categories are listed as Investigation of Force, Investigation of Procedure, and Investigation of Courtesy. The main focus of the CRB is to determine the fairness, thoroughness and timeliness of the investigation, as well as any possible deficiencies. Where appropriate, a panellist (or panellists) may make training, investigative, or policy recommendations to the Chief of Police and the Professional Standards Section. Should the review panel conclude that the investigation is inadequate in any manner, it is returned to the investigating Sergeant with the reasons stated. Once the follow-up investigation is complete, that investigation is returned to the same panel for review and recommended findings. The panel may then call for the Recommended Findings, or if not satisfied with the packet, the panel may return the packet to the command officer in the Professional Standards Section. Possible recommended findings are:

1) Sustained: the act occurred, and the act amounts to misconduct or misjudgement;

2) Unprovable: there is insufficient evidence to prove or to disprove an allegation;

3) Unfounded: the act complained of did not apparently occur;

4) Exonerated: The RPD personnel's conduct was justified, lawful and proper.

The findings and recommendations of the Civilian Review Board are forwarded to the Chief of Police for review. The Chief then issues a final decision on all complaints, and determines any remedial or disciplinary action.

\subsection{Complainants may appeal findings established by the police or sheriff's department to citizens, who review them and then recommend their own findings to the chief or sheriff. Example: Police Internal Investigations Auditing Committee (PIIAC)}

Portland's citizen review mechanism, the PIIAC, was created in 1982. 29 City Council members make up PIIAC, with investigations conducted by PIIAC citizen advisors, who are volunteers drawn largely from neighbourhood associations. They do not conduct independent investigations of complaints received by PIIAC, but instead meet once a month to hear appeals from citizens dissatisfied with police internal investigations of their complaints and to perform random audits of internal investigations and 
review all closed use of force cases. Their review is limited to determining whether a complete and unbiased investigation took place, rather than deciding a case's merit. If they believe the investigation was sub-standard, they may request that the Internal Affairs Division (IAD) conduct a more thorough investigation. When an individual appeals IAD's findings, the PIIAC may re-examine the investigation and the city council may rule the complaint sustained. When a complaint is sustained, the police chief makes all disciplinary decisions.

PIIAC's citizen advisors submit quarterly reports to the mayor and City Council, highlighting shortcomings in investigations and abuse trends and recommending reforms. The reports also include IAD statistics regarding received complaints and their status.

According to PIIAC and IAD, sometimes IAD receives a complaint, investigates the incident, and finds the officer responsible for an offense different than the one described in the complaint. For example, while an individual's complaint that an officer used excessive force may be found not sustained by the IAD, it might find another offense occurred, such as not reporting the use of force. PIIAC has expressed concern that while complainants receive notification that a complaint was sustained, IAD does not explain that the offense reported in the original complaint was not the offense sustained, thus misinforming the complainant.

PIIAC's mandate includes analysis of civil lawsuits against the police (risk management data), but it has expressed concern that IAD does not use these data as part of the 'command review' for purposes of identifying officers with repeated complaints of abuse. ${ }^{35}$

Some civilian review experts believe the PIIAC auditor system works better than other city review boards with broader responsibilities. Civilian review expert Sam Walker sees '...the promise of some real progress with the auditor model that I don't quite see with other traditional civilian complaint review boards. ${ }^{36}$ Even the police union has approved of PIIAC's approach. The former president of the local police union was quoted as

35 In its May 1995 report, PIIAC wrote, 'the Portland Police Bureau has assured the advisory committee that they [sic] are working on ways to better utilize risk management information; however, we see no evidence that the information is being used for command review purposes as mandated by the mayor's police/citizen accountability initiative... Command Review would be more effective if it could tap the information that comes through risk management.' PIIAC 1997 first-quarter report.

36 National Public Radio's Morning Edition, 31.7.1997, quoting Sam Walker, https:// www.hrw.org/legacy/reports98/police/uspo118.htm\#P3217_848251. 
stating, 'It gives them [citizens] a window to look in there to be sure that this isn't a secret room... where we're in ninja suits conducting some secret cover-up. We can't cover up... ${ }^{37}$ Others believe that PIIAC fully utilizes its mandate but that, without the ability to receive initial complaints, conduct its own independent investigation, or recommend discipline in sustained cases, it is overly reliant on the police bureau's cooperation. These concerns are reinforced by the fact that, no matter what PIIAC finds, the police chief is under no obligation to accept its findings, despite its neutral examination of the same facts reviewed by the IAD in making its determination.

\subsection{An auditor investigates the process by which the police or sheriff's department accepts and investigates complaints and reports on the thoroughness and fairness of the process to the department and the public. Example: Tucson Independent Police Auditor (IPA) and Citizen Police Advisory Review Board (CPAB)}

In March 1997, the mayor and city council replaced the old board with a new and more powerful Citizen Police Advisory Review Board.

At the same time (July 1997), they established a new position of independent police auditor. The Office of the Independent Police Auditor was established as an external source to audit citizen complaint investigations conducted by the Tucson Police Department Office of Internal Affairs (OIA). The audit purpose is to determine if an OIA investigation was complete, thorough, objective and fair. The Office of the IPA is a resource for citizens of Tucson regarding police actions and standards. The auditor's principal responsibilities are to:

1) Serve as an alternative to the police department for accepting citizen complaints;

2) Monitor ongoing investigations as needed by sitting in on internal affairs interviews;

3) Proactively audit, that is review, completed IA investigations of citizen complaints for fairness and thoroughness;

37 Ibid., quoting PPB Sgt. Jeff Barker of the Internal Affairs Division. Another effort at transparency, led by community activists, has resulted, in most cases, in the opening of appeal hearings to the public. 
4) Review cases in which a citizen expresses dissatisfaction with the police department's resolution of a complaint.

When the OIA has completed its investigation, the IPA and the complainant will be notified as to the outcome. If the complainant is not satisfied with the outcome of the investigation, he/she may request a review by the IPA. Once the IPA has completed the review, the complainant will be notified of the outcome.

The Citizen Police Advisory Review Board has seven voting members. It also has seven nonvoting members: four community advocate members and one member each appointed by the city manager's office, police department, and police union. Complainants who are dissatisfied with the IA investigation or the auditor's review may ask the board to review their cases. If the board agrees to review the complaint, it requests and receives IA case files to examine between meetings. The board may ask IPA to undertake an additional investigation or answer questions about the case if the auditor has already audited the case. After hearing from IPA, the board may recommend a different finding to the chief or the city council, but it has no power to enforce its recommendations. About eight citizens a month call their council representatives to complain about alleged police misconduct.

\section{Conclusion}

The paper presents a general review of the material in question and examines various forms of oversight from a world perspective. The above examples from Great Britain, India and the USA have revealed that oversight mechanisms first vary from one country to another in terms of establishment and sustainability. Democratic policing is now a widely and more increasingly used approach to policing around the world. New challenges produced both by the media and the law as well as internal command and control issues call for the basic reformulation of the foundations of democratic policing. The establishment of oversight institutions over police actions is undoubtedly a key element of democratic policing. Important opportunities to promote oversight may emerge from broader political changes or reforms such as the election of new political leaders, transitions to democracy, or through implementing a system of protecting human rights.

Being often preoccupied with responding to complaints and misconducts, civilian oversight stands also for proactive approaches to reforming 
or influencing police. Successful oversight involves being proactive in the study of individual cases and misconduct issues into the broader areas of police policy both in a way of analysing problems, identifying their causes and offering solutions. A supervisory of police misconduct by oversight agencies also comprises a proactive focus on identifying and addressing underlying systemic problems within police organizations themselves. Arguments for oversight have often been dedicated to the effectiveness of oversight in addressing complaints, misconduct or broader police policy.

The oversight of police conduct is a fundamental governance issue and relates to concerns about democratisation and building a civil society. Therefore, the effectiveness of oversight should constitute a basic factor responding to police misconduct or broader areas of police policy, enhancing the legitimacy of the police in the eyes of the public. There are some common features associated with countries that have embraced this scheme includes the system of democracy, the protection of human rights and the way the justice system is administered.

Since the 1970s and 1980s, several countries in the West have introduced policies that permitted citizens to have an active role in the oversight of the police. Civilian oversight is a relatively new method of police accountability, which has been implemented in a wide range of jurisdictions around the world. Nowadays, increasingly more new countries introduce different forms of police accountability and many are turning to civilian oversight bodies to improve the process. There are two kinds of the civilian oversight mechanisms that have been concerned with complaints against the police: those organizations that take primary responsibility for receiving and investigating complaints and those bodies that do not investigate complaints nevertheless are involved in the review and monitoring of investigations. These mechanisms function as bridges between the police and the public. Undoubtedly, there are several important factors and manners for countries engaged in the implementation and development of the oversight mechanisms still to be considered.

\section{Bibliography}

1. Aitchison, A., J. Blaustein, Policing for Democracy or Democratically Responsive Policing? Examining the Limits of Externally Driven Police Reform, 'European Journal of Criminology' 2013, vol. 10, no. 4.

2. Aitchison, A., Police Reform in Bosnia and Herzegovina: State, Democracy and International Assistance, 'Policing and Society' 2007, vol. 17, no. 4. 
3. Alderson, J., Policing Freedom, Dilemmas of Policing in Western Democracies, Macdonald and Evans, Plymouth 1979.

4. Alemika, E. E., Police oversight agencies in West Africa, 2005, available at www.policeaccountability.co.za.

5. Alemika, E. E., Police reform and oversight, Police reform in Africa: Issues and challenges. IDASA, Police reform in post-conflict African countries conference, Pretoria, South Africa 12-15 March 2007. Cape Town Institute of Criminology, 2007.

6. Amir, M., S. Einstein (eds), Policing, Security and Democracy: Theory and Practice, Office of International Criminal Justice, Huntsville 2001.

7. Aremu, A., F. Pakes, L. Johnston, The effect of locus of control in the reduction of corruption in the Nigerian police, 'Policing' 2009, vol. 32, no. 1.

8. Attard, B., Oversight of Law Enforcement is Beneficial and Needed-Both Inside and Out, 'Pace Law Review' 2010, vol. 30, no 5. Opening Up a Closed World: A Sourcebook on Prison Oversight, p. 1550.

9. Baranyi S., J. B. Salahub, Police reform and democratic development in lower-profile fragile states, 'Canadian Journal of Development Studies' 2011.

10. Bayley, D. H., Changing the Guard: Developing Democratic Policing Abroad, OUP, New York 2006.

11. Beattie, C., R. Weitzer, Race, Democracy and Law: Civilian Review of Police in Washington, DC [in:] A. Goldsmith, C. Lewis, (eds), 'Civilian Oversight of Policing', Hart Publishing, Oxford 2000.

12. Bierschenk, T., The everyday functioning of an African public service. Informalization, privatization and corruption in Benin's legal system, 'Journal of Legal Pluralism' 2008.

13. Bradley, D., N. Walker, R. Wilkie, Managing the Police: Law, Organisation and Democracy, Wheatsheaf, Brighton 1986.

14. Bronwen M., The South African Independent Complaints Directorate [in:] A. Goldsmith, C. Lewis, (eds), 'Civilian Oversight of Policing', Hart Publishing, Oxford 2000.

15. Building Public Confidence in Police through Civilian Oversight, Vera Institute of Justice, September 2002.

16. Buren, B.A., Evaluating Citizen Oversight of Police, LFB Scholarly Publishing, New York 2007.

17. Casey, C., Policing through Violence: Fear, Vigilantism and the Politics of Islam in Northern Nigeria [in:] D. Pratten, A. Sen (eds), 'Global Vigilantes', Hurst, London 2007.

18. Chanda, A.W., Lecture Series: Human Rights for Law Enforcement Officers, the Zambia Legal Information Institute, 2004: http://www.zamlii.ac.zm/media/ news/viewnews.cgi?category=2\&id $=1069084655$.

19. Changwon, P., Background Report Examining Existing Police Oversight Mechanisms in Asia. Presented at the workshop: Improving the Role of the Police in Asia and Europe. Delhi, India, 3-4.12.2008. 
20. M. Chingono, The State, Violence and Development: The Political Economy of War in Mozambique 1975-92, Aldershot 1996.

21. Das D., O. Marenin (eds), Challenges of Policing Democracies, Gordon and Breach Science Publishers, Newark 2000.

22. Finn, P., Citizen Review of Police: Approaches and Implementation, National Institute of Justice, March 2001.

23. Flemming, J., C. Lewis, The Politics of Police Reform [in:] T. Prenzler, J. Ransley (eds), 'Police Reform - Building Integrity', Hawkins Press, Annandale 2000.

24. Freckelton, I., Shooting the Messenger: The Trial and Execution of the Victorian Police Complaints Authority [in:] A. J. Goldsmith (ed.) 'Complaints Against the Police: The Trend to External Review', Clarendon, Oxford 1991.

25. Harris, F., Holding Police Accountability Theory to Account, 'Policing: Journal of Policy and Practice', vol. 6, no. 3.

26. Harrison, J., M. Cunneen, An Independent Police Complaints Commission, Liberty, 2000.

27. Heald, S., Controlling Crime and Corruption from Below: Sungusungu in Kenya, 'International Relations' 2007, vol. 21.

28. Jones, T., Newburn T., Smith D., Policing and the Idea of Democracy, 'British Journal of Criminology' 1996, vol. 36, no. 2.

29. Lambert, J., Police Powers and Accountability, Croom Helm, Kent 1982.

30. Lewis, C., Complaints against Police - The Politics of Reform, Hawkins, Sydney 1999.

31. Livingston, D., The Unfulfilled Promise of Citizen Review, 'Ohio State Journal of Criminal Law' 2004, vol. 1, no. 2.

32. Loveday, B., Government and Accountability of the Police [in:] R. I. Mawby (ed.) 'Policing across the World: Issues for the Twenty-first Century', Routledge, London 1999.

33. Ławrynowicz-Mikłaszewicz, M., Bezpieczeństwo jako prawo człowieka w kontekście stosowania środków przymusu bezpośredniego i broni palnej przez uprawnione podmioty, 'Przegląd Prawniczy, Ekonomiczny i Społeczny' 2014, no. 4.

34. Maguire, M., Complaints against the Police: The British Experience [in:] A. J. Goldsmith (ed.) 'Complaints Against the Police: The Trend to External Review' Clarendon, Oxford 1991.

35. Manby, B., The South African Independent Complaints Directorate [in:] A. Goldsmith, C. Lewis, (eds), 'Civilian Oversight of Policing', Hart Publishing, Oxford 2000.

36. Manning, P. K., Democratic policing in a changing world, Paradigm Publishers, London 2010.

37. Mansley, D. R., Collective Violence, Democracy and Protest Policing, Routledge, London 2013. 
38. Marenin, O., The Goal of Democracy in International Police Programs. Policing: An International Journal of Police Strategies and Management 21(1), 1998.

39. Marenin, O., The Goal of Democracy in International Police Assistance Programs, 'Policing; an International Journal of Police Strategies and Management' 1998, vol. 21, no. 2.

40. Marks, M., A. Goldsmith, The state, the people and democratic policing: the case of South Africa [in:] J. Wood, B. Dupont (eds) 'Democracy, Society and the Governance of Security' Cambridge University Press, 2006.

41. Melville, N., The Taming of the Blue: Regulating Police Misconduct in South Africa, Pretoria 1999.

42. Merrick, B., Civilian Oversight of the Police in the United States, 'Saint Louis University Public Law Review' 2003, vol. 22, no. 1.

43. Merrick, B., Internal and External Oversight in the U.S., PARC issues paper, October 2005.

44. Miller, J., Civilian oversight of policing. Lessons from the Literature, Vera Institute of Justice. Global Meeting on Civilian Oversight of Police, Los Angeles, 5-8.5.2002, http://www.vera.org/publication_pdf/178_338.pdf.

45. Milton-Edwards, B., Called to Account: Civilian Oversight in the Palestinian Context [in:] A. Goldsmith, C. Lewis (eds.), 'Civilian Oversight of Policing', Hart Publishing, Oxford 2000.

46. Neild, R., Confronting the culture of Impunity: The Promise and Pitfalls of Civilian Review of Police in Latin America [in:] A. Goldsmith, C. Lewis, (eds.), 'Civilian Oversight of Policing' Hart Publishing, Oxford 2000.

47. Newburn, T., M. Hinton (eds.), Policing Developing Democracies, Routledge, London 2008.

48. Newham G., T. Masuku, J. Dlamini, Diversity and Transformation in the South African Police Service: A study of police perspectives on race, gender and the community in the Johannesburg policing area, Centre for the Study of Violence and Reconciliation, 2006.

49. Perez, D. W., Common Sense About Police Review, Philadelphia 1994.

50. Piechowiak, M., Klauzula limitacyjna a nienaruszalność praw i godności, 'Przegląd Sejmowy' 2009, no. 2.

51. Pino, N. W., Wiatrowski, M. D., Democratic Policing in Transitional and Developing Countries Ashgate 2006.

52. Police Assessment Resource Center, Review of National Police Oversight Models for the Eugene Police Commission, February 2005.

53. Reiner, R., Multiple Realities, Divided Worlds: Chief Constables' Perspectives on the Police Complaints System [in:] A. J. Goldsmith (ed.) 'Complaints Against the Police: The Trend to External Review', Clarendon, Oxford 1991.

54. Revisiting 'Who is Guarding the Guardians?', November 2000, http://www. usccr.gov/pubs/pubsndx.htm; U.S. Commission on Civil Rights, Who is Guarding the Guardians? A Report on Police Practices, 1981. 
55. Safjan, M., Wyzwania dla państwa prawa, Warszawa 2007.

56. Shaw, M., Crime and Policing in Post-Apartheid South Africa: Transforming under Fire, Hurst, London 2002.

57. Simmons, K. Ch., The Politics of Policing: Ensuring Stakeholder Collaboration in the Federal Reform of Local Law Enforcement Agencies, 'Journal of Criminal Law and Criminology' 2008, vol. 98, no. 2.

58. Smit, B. F., Botha, C. J., Democracy and policing: an introduction to paradox, 'Acta Criminologica' 1990, vol. 3, no. 1.

59. Smith, G., Rethinking Police Complaints, 'The British Journal of Criminology' 2004, vol. 44, no. 1.

60. Sokolewicz, W., Komentarz do art. 2, [in:] L. Garlicki (ed.), 'Konstytucja Rzeczypospolitej Polskiej. Komentarz', vol. V, Warszawa 2007.

61. Stępkowski, A., Zasada proporcjonalności w europejskiej kulturze prawnej, Warszawa 2010.

62. Stone, Ch. E., Ward, H. H., Democratic Policing: A Framework for Action, 'Policing and Society' 2000, vol. 10, no. 1.

63. Tankebe, J., Police effectiveness and police trustworthiness in Ghana, 'Criminology and Criminal Justice' 2008, vol. 8, no. 2.

64. Tankebe, J., Public confidence in the police: testing the effects of public experiences of police corruption in Ghana, 'British Journal of Criminology' 2010, vol. 50, no. 2.

65. Tertsakian, C., State-sponsored terrorism. The Bakassi boys; the legitimization of murder and torture, 'Human Rights Watch' 2002, vol. 14, no. 5.

66. Under the Spotlight: complaints against the AFP and NCA, Australian Law Reform Commission, Australia Government Publishing Service, 1995.

67. von Schnitzler, A., G. Ditlhage, L. Kgalema, T. Maepa, T. Mofokeng, P. Pigou, Guardian or Gangster? Mapogo a Mathamaga: A Case Study, 'Violence and Transition Series' 2001, vol. 3, available at http://www.csvr.org.za/papers/ papvtp3.htm.

68. Walker, S., Police Accountability: The Role of Citizen Oversight, Wadsworth Professionalism in Policing Series, Belmont 2001.

69. Walker, S., The New World of Police Accountability, Thousand Oaks 2005.

70. Waseem, S., The independent police complaints commission: who will guard the guardians?, Islamic Human Rights Commission, 2005.

71. Wojtyczek, K., Zasada proporcjonalności jako granica prawa karania, [in:] A. Zoll (ed.), 'Racjonalna reforma prawa karnego', Warszawa 2001.

72. Zoll, A., Konstytucyjne aspekty prawa karnego, [in:] T. Bojarski (ed.), 'Źródła prawa karnego. System Prawa Karnego', vol. 2, Warszawa 2011. 